\title{
PENGGUNAAN MEDIA POWER POINT UNTUK MENINGKATKAN KUALITAS HASIL BELAJAR SISWA DALAM MEMPELAJARI LETAK DAN LUAS BENUA DI KELAS IX-4 MTS NEGERI 7 BLITAR TAHUN PELAJARAN 2018-2019
}

\author{
HAMIM TOHARI \\ MTs Negeri 7 Blitar \\ hamimjoglo@gmail.com
}

\begin{abstract}
ABSTRAKSI
Tujuan dari penelitian ini adalah untuk membuat suatu desain pembelajaran IPS berbasis Power Point yang dapat meningkatkan kualitas hasil belajar siswa kelas IX-4 MTs Negeri 7 Blitar dalam mempelajari Letak dan Luas Benua. Penelitian ini menggunakan penelitian tindakan (action research) sebanyak tiga siklus di MTs Negeri 7 Blitar Setiap siklus terdiri dari empat tahap yaitu : rancangan, kegiatan dan pengamatan, refleksi, dan refisi. Sasaran penelitian ini adalah siswa kelas. Data yang diperoleh berupa hasil tes formatif, lembar observasi kegiatan belajar mengajar. Dari hasil analisis didapatkan bahwa prestasi belajar siswa kelas IX-4 MTs Negeri 7 Blitar mengalami peningkatan dari siklus I sampai siklus II, yakni siklus I (66\%), siklus II (100\%). Kesimpulan dari penelitian ini adalah desain pembelajaran berbasis media Power Point layak digunakan dalam pembelajaran dan dapat meningkatkan kualitas hasil belajar IPS peserta didik MTs Negeri 7 Blitar pada materi letak dan luas benua dengan kategori sangat baik. Karena ada peningkatan aktifitas dan hasil belajar peserta didik dalam pelajaran IPS dapat digunakan sebagai salah satu alternatif pembelajaran IPS.
\end{abstract}

Kata Kunci : Aktifitas belajar, media pembelajaran.

\section{PENDAHULUAN}

Tujuan dari pembelajaran IPS tersebut dapat tercapai dengan cara mendesain pembelajaran. Desain pembelajaran merupaan praktik pembuatan alat dan isi materi pembelajaran agar proses belajar berlangsung seefektif mungkin. Proses dimaksud secara garis besar meliputi penentuan kebutuhan belajar pesertadidik, menentukan tujuan pembelajaran, dan menciptakan kegiatan atau "intervensi" dalam rangka mencapai tujuan pembelajaran. Idealnya proses dimaksud didasarkan atas teori belajar yang valid. Hasil pembelajaran dapat berupa perubahan perilaku peserta didik yang secara langsung atau tidak langsung dapat di amati dan diukur.

Seperti yang dikemukakan oleh Michigan University dalam Gafur (2012:2) menyatakan "Desain pembelajaran merupakan proses sistematis pengembangan paket pembelajaran menggunakan teori belajar dan teori pembelajaran untuk menjamin terwujudnya pembelajaran yang berkualitas".

Salah satu cara mendesain pembelajaran yaitu dengan menggunakan media persentasi yang menarik. Media pembelajaran yang dapat di lakukan untuk mengatasi kendala kendala di atas adalah media program Microsoft Power Point. Media pembelajaran merupakan perantara untuk menyalurkan pesan antara sumber (guru) dengan penerima pesan (peserta didik) dalam memahami materi pembelajaran saat terjadinya proses pembelajaran agar lebih efektif dan efesien yang dikemas dalam bentuk yang menarik. Media Program Microsoft Power Point adalah program aplikasi presentasi yang populer dan paling banyak digunakan saat ini untuk berbagai kepentingan presentasi dalam proses pembelajaran. Adapun distribusi frekuensi hasil belajar Ilmu Pengetahuan Sosial (IPS) siswa kelas IX-4 MTs Negeri 7 Blitar pada siklus II dikategorisasikan pada tabel 4.9 dibawah ini : 
Tabel 1. Klasifikasi hasil belajar peserta didik setelah mendesain pembelajaran menggunakan media Power Point.

\begin{tabular}{|c|c|c|c|c|}
\hline No & Nilai & Kategori & Frekuensi & Persentase \\
\hline 1 & $80-100$ & $\begin{array}{c}\text { Sangat baik/Sangat } \\
\text { tinggi }\end{array}$ & 28 & 97 \\
\hline 2 & $70-79$ & Baik/tinggi & 1 & 3 \\
\hline 3 & $60-69$ & Sedang & 0 & 0 \\
\hline 4 & $50-59$ & Kurang & 0 & 0 \\
\hline 5 & $\leq 49$ & Sangat kurang & 0 & 0 \\
\hline \multicolumn{3}{|c|}{ Jumlah } & 29 & 100 \\
\hline
\end{tabular}

Berdasarkan Tabel 1. dapat diketahui bahwa peserta didik yang mendapatkan nilai rendah sudah berkurang, artinya hampir semua peserta didik memperoleh nilai yang sangat baik. Hal ini dikarenakan peserta didik sudah memahami materi pelajaran yang disampaikan, oleh sebab itu, peserta didik sudah lebih aktif untuk mengikuti pembelajaran sehingga mencapai nilai ketuntasan dan nilai ideal.

Dari hasil refleksi tersebut peneliti mendapatkan saran yaitu agar desain media Power Point yang telah dibuat untuk mata pelajaran sebaiknya terus digunakan nantinya dalam proses pembelajaran terutama pada pelajaran IPS untuk meningkatkan minat peserta didik dalam belajar juga meningkatkan pemahaman peserta didik. Karena dengan di desainnya pembelajaran menggunakan Power Point mampu meningkatkan keaktifan peserta didik secara tidak langsung juga meningkatkan hasil belajar IPS peserta didik terutama pada materi peran sumber daya alam dalam proses pembelajaran IPS. Hal ini dapat dilihat dari hasil tabel-tabel di atas.

\section{METODE PENELITIAN}

Metode penelitian yang digunakan dalam penelitian ini adalah penelitian dan pengembangan atau Research And Development $(R \& D)$, merupakan metode Penelitian yang digunakan untuk mengembangkan dan menghasilkan suatu produk dengan menggunakan uji coba Penelitian Tindakan Kelas (Class Action Research) karena dalam penelitian ini akan dilakukan tindakan (Action) menemukan dan memecahkan masalah, dan akan di ukur sampai dimana tingkat keoptimalan tindakan dapat meningkatkan motivasi belajar dan hasil belajar peserta didik di dalam kelas dengan mendesain pembelajaran IPS berbasis media Power Point. Rancangan yang digunakan adalah model rancangan yang diadaptasi Stephen Kemmis dan Mc. Taggart (1998) dengan menggunakan dua siklus, dengan masing-masing siklus terdiri dari empat tahapan yaitu: (1) perencanaan, (2) tindakan, (3) pengamatan, dan (4) refleksi.

Siklus pertama dilakukan dengan tahapan sebagai berikut : 1) Perencanaan, pada tahap ini akan dilakukan pembuatan RPP dan mengembangkan skenario pembelajaran. 2) Tindakan, tahap ini melaksanakan tindakan sesuai dengan skenario yang telah direncanakan yaitu menyampaikan materi pembelajaran dengan menggunakan media Power Point. 3) Pengamatan, pada tahap ini peneliti/guru mengamati proses kegiatan yang sedang berlangsung, diantaranya : mengamati interaksi belajar peserta didik saat ditayangkan materi pelajaran dalam media Power Point dan menilai lembar kerja yang telah dikerjakan peserta didik. 4) Refleksi, pada tahap ini dilakukan untuk evalusi seluruh tindakan yang dilakukan berdasarkan hasil pengamatan dan menyusun rencana perbaikan sesuai dengan kelemahan-kelemahan pada yang terjadi berdasarkan hasil pengamatan untuk digunakan pada siklus kedua. Indikator yang dapat dilakukan adalah melihat hasil pada lembar latihan peserta didik (jika hasilnya belum mencapai 75\% maka akan lakukan perbaikan pada siklus kedua dengan materi yang sama, dan jika hasilnya sudah memuakan maka pada siklus kedua akan disampaikan materi selanjutnya).

Pada siklus kedua proses pembelajaran tahapan yang dilakukan meliputi : 1) Perencanaan, pada tahap ini akan dilakukan identifikasi masalah pada siklus pertama dan menyusun alternatif pemecahannya, serta menyiapkan media pembelajaran dan materi yang 
akan disampaikan. 2) Tindakan, peneliti/guru menjelaskan materi letak dan luas benua dengan menyisipkan suara pada tayangan power point, dan menjelang akhir jam pelajaran peneliti/guru melakukan tanya jawab dan menjelaskan kesimpulan dari kegiatan belajar. 3) Pengamatan, peneliti/guru mengamati proses kegiatan yang sedang berlangsung, diantaranya : mengamati interaksi belajar ketika ditayangkan materi pelajaran dalam media power point dan menilai lembar kerja yang telah dikerjakan peserta didik. 4) Refleksi, pada tahap ini dilakukan evalusi seluruh tindakan berdasarkan hasil pengamatan dan penilaian juga membuat suatu kesimpulan dari hasil pengamatan dan penilaian tersebut.

\section{HASIL DAN PEMBAHASAN}

\section{A. Deskripsi Data Hasil Penelitian}

\section{Hasil analisis sebelum tindakan (data awal)}

Sebelum melaksanaan tindakan penelitian, guru/peneliti melakukan ulangan harian kepada peserta didik. Ulangan harian IPS pada pokok bahasan letak dan luas benua yang dilaksanakan pada hari Selasa 04 September 2018, dimana dilakukan ulangan harian pra tindakan yang bertujuan untuk mengetahui penguasaan peserta didik dalam materi letak dan luas benua yang dijadikan topik pembahasan sebelum penelitian tindakan kelas dilaksanakan. Dimana didalam proses pembelajarannya dilaksanakan secara konvensional dan belum mendesain pembelajaran menggunakan media Power Point ternyata hasilnya kurang memuaskan.

Dari hasil belajar IPS peserta didik terlihat bahwa hasil belajar peserta didik kelas IX-4 MTs Negeri 7 Blitar, memperoleh nilai rata-rata 60 atau ketuntasan hanya mencapai $28 \%$ termasuk dalam kategori sangat rendah. Hal tersebut dikarenakan ulangan harian tentang letak dan luas benua merupakan materi yang banyak menggunakan pengamatan dalam proses pembelajarannya, sehingga kalau pembelajarannya masih menggunakan metode konvensional akan menyulitkan siswa untuk memamahaminya. Hal ini memberikan indikator bahwa proses pembelajaran belum mencapai tujuan yang diharapkan peneliti yang tertuang dalam indikator keberhasilan pembelajaran yaitu mencapai ketuntasan individual yaitu sesuai KKM yang telah ditentukan sekolah (75), sehingga perlu mendesain pembelajaran yang berbasiskan media Power Point sehingga hasil belajar peserta didik meningkat.

\section{Deskripsi data siklus I}

Pada tahap ini dilaksanakan kegiatan uji coba menggunakan desain media Power Point, pelaksanaan tindakan siklus I berlangsung selama 2 kali pertemuan dengan lama waktu dalam setiap pertemuan yaitu 2x40 menit yang dilaksanakan pada hari selasa 11 September 2018 (sesuai dengan roster mata pelajaran). Pembelajaran siklus I ini berlangsung selama 4x40 menit (120 menit). Pada saat pertemuan dihadiri oleh keseluruhan peserta didik yaitu 29 anak.

Hasil observasi siklus I menujukkan bahwa jumlah peserta didik yang hadir pada saat proses pembelajaran berlangsung adalah 29 siswa. Peserta didik yang mengamati Power Point sebanyak 16 siswa, dan selebihnya disebabkan karena peserta didik yang sibuk sendiri, kurangnya peserta didik yang mencatat indikator disebabkan karena peserta didik yang malas menulis dan merasa bosan. Kurangnya peserta didik yang meminta bimbingan disebabkan karena peserta didik merasa takut untuk berbicara, peserta didik belum percaya diri sehingga enggang untuk berbicara pada guru. Kurangnya peserta didik yang aktif disebabkan peserta didik yang takut salah saat mengemukaan pendapatnya, dan juga tidak percaya diri. Kurangnya peserta didik yang dapat menyimpulkan pelajaran disebabkan karena tidak memperhatikan pelajaran sehingga tidak mereka tidak tahu apa yang harus disimpulkan. Hal ini berarti ketercapaian indikator belum tercapai, sehingga penelitian dilanjutkan pada siklus II.

Tabel 2. Klasifikasi hasil belajar peserta didik setelah mendesain pembelajaran menggunakan media Power Point.

\begin{tabular}{|c|c|c|c|c|}
\hline No & Nilai & Kategori & Frekuensi & Persentase \\
\hline 1 & $80-100$ & Sangat baik/Sangat tinggi & 10 & 35 \\
\hline
\end{tabular}


ACTION : Jurnal Inovasi Penelitian Tindakan Kelas dan Sekolah

Vol 1. No 1. Juli 2021 e-ISSN : 2798-5733 P-ISSN : 2798-5741

\begin{tabular}{|c|c|c|c|c|}
\hline No & Nilai & Kategori & Frekuensi & Persentase \\
\hline 2 & $70-79$ & Baik/tinggi & 12 & 41 \\
\hline 3 & $60-69$ & Sedang & 5 & 17 \\
\hline 4 & $50-59$ & Kurang & 2 & 7 \\
\hline 5 & $\leq 49$ & Sangat kurang & 0 & 0 \\
\hline \multicolumn{3}{|c|}{ Jumlah } & 29 & 100 \\
\hline
\end{tabular}

\section{Deskripsi data siklus II}

Pada tahap pelaksanaan tindakan siklus II berlangsung selama 2 kali pertemuan dengan lama waktu dalam setiap pertemuan yaitu 2x40 menit yang dilaksanakan pada hari selasa 25 September 2018 (sesuai dengan roster mata pelajaran). Pembelajaran siklus II ini berlangsung selama 4x40 menit (120 menit). Pada pertemuan ini dihadiri oleh keseluruhan peserta didik yaitu 29 anak.

Hasil observasi siklus II menujukkan bahwa bahwa hampir semua peserta didik beraktivitas sesuai indikator, hasil persentase tingkat observasi sebesar $90 \%$ ini menujukkan bahwa aktivitas peserta didik pada siklus II jika dikategorisasikan berada pada kategori sangat tinggi, aktivitas peserta didik meningkat dari siklus sebelumnya, Hal ini berarti ketercapaian indikator sudah tercapai, peserta didik sudah mengerti dan terbiasa menggunakan media Power Point dalam pembelajaran. Sehingga dengan demikian penelitian tidak perlu lagi dilanjutkan pada siklus berikutnya.

Tabel 3. Klasifikasi hasil belajar peserta didik setelah mendesain pembelajaran menggunakan media PowerPoint.

\begin{tabular}{|c|c|c|c|c|}
\hline No & Nilai & Kategori & Frekuensi & Persentase \\
\hline 1 & $80-100$ & Sangat baik/Sangat tinggi & 28 & 97 \\
\hline 2 & $70-79$ & Baik/tinggi & 1 & 3 \\
\hline 3 & $60-69$ & Sedang & 0 & 0 \\
\hline 4 & $50-59$ & Kurang & 0 & 0 \\
\hline 5 & $\leq 49$ & Sangat kurang & 0 & 0 \\
\hline \multicolumn{3}{|r|}{ Jumlah } & 29 & 100 \\
\hline
\end{tabular}

\section{B. Pembahasan}

\section{Penilaian kelayakan desain pembelajaran berbasis media PowerPoint}

Sebelum dilakukan penilaian kelayakan desain media Power Point terlebih dahulu dilakukan analisis perangkat pembelajaran dan instumen penelitian. Hasil analisis data yang telah dilakukan dapat digunakan untuk melihat sejauh mana baik tidaknya perangkat pembelajaran dan instrument penelitian yang telah dirangcang. Perangkat yang dirangcang dalam hal ini ialah rencana pelaksanaan pembelajaran, lembar kegiatan peserta didik, dan instrument penelitian yang dirangcang dalam hal ini lembar instrument penilaian untuk validator, lembar instrument penilaian oleh peserta didik, lembar angket motivasi dan tes hasil belajar peserta didik. Penilaian perangkat pembelajaran dan instrumen oleh para ahli sebelum menggunakan desain media pembelajaran berbasis Power Point terlebih dahulu dinilai kelayakannya berdasarkan pada dua hal, yaitu penilaian dari validator dan data empirik hasil respon peserta didik terhadap pembelajaran menggunakan media pembelajaran berbasis Power Point. Penilaian oleh validator diberikan sebelum menggunakan media dalam pembelajaran peneliti membagikan lembar penilaian kepada validator untuk melihat kelayakan media pembelajaran, mulai dari aspek audio visual, aspek isi, aspek penyajian, dan aspek menyeluruh.

Dari hasil penelitian menunjukkan bahwa media pembelajaran sudah layak untuk digunakan di sekolah sebagai bahan ajar tambahan. Sedangkan instrument respon peserta didik diberikan pada akhir pertemuan siklus II. Penilaian oleh peserta didik dilihat dari dua aspek yakni aspek strategi pemebelajaran dan aspek tampilan. Dari hasil instrument respon siswa, 
didapatkan desain media yang telah digunakan berada pada kategori layak.ini menunjukkan bahwa media tersebut dapat di produksi untuk digunakan dalam skala besar. Hasil penilaian para pakar digunakan sebagai dasar penilaian hasil revisi dan penyempurnaan terhadap desain media pembelajaran. Media pembelajaran direvisi berdasarkan masukan dari para validator ini selanjutnya digunakan dalam penelitian.

\section{Perubahan Aktivitas dan Hasil Belajar Peserta didik}

Berdasarkan hasil analisis kuantitatif dan kualitatif, terlihat bahwa pada dasarnya pelaksanaan pembelajaran peningkatan kualitas hasil belajar IPS melalui pembelajaran menggunakan desain media Power Point di kelas IX-4 MTs Negeri 7 Blitar dapat memberikan perubahan nilai dan perilaku peserta didik dalam belajar. Selain itu, membentuk jiwa peserta didik yang lebih aktif dalam kegiatan pembelajaran. Perubahan tersebut pada kebiasaan peserta didik yang dilakukan sebelum dilaksanakannya pengajaran menggunakan desain media PowerPoint yang ketika pembelajaran sedang berlangsung mereka tidak memperhatikan penjelasan guru. Setelah mendesain terlihat ada peningkatan aktivitas dan hasil belajarnya.

Pada siklus I peserta didik masih terlihat bingung dengan tugas mereka di kelas, hal ini dapat disebabkan pembelajaran dengan media Power Point merupakan hal baru dan belum diterapkan sebelumnya sehingga pencapaian hasil belajar yang dicapai peserta didik belum maksimal. Dengan usaha dan bimbingan yang tekun diharapkan dapat meningkatkan motivasi peserta didik dengan harapan dapat meningkatkan pencapaian hasil belajar peserta didik yang lebih baik. Salah satu faktor yang menentukan berhasil atau tidaknya seseorang dalam belajar adalah faktor yang berasal dari dalam diri orang yang belajar (internal) bahwa hasil belajar dipengaruhi oleh faktor internal: tujuan, minat belajar, aktivitas, kecakapan, kebiasaan belajar, serta penguasaan bahan mata pelajaran.

Setelah dilakukan refleksi kegiatan pada siklus satu, maka dilakukan beberapa perbaikan kegiatan yang dianggap perlu demi meningkatkan motivasi dan hasil belajar peserta didik dengan mendesain pembelajaran berbasiskan media Power Point. Pada siklus dua. Pada siklus dua selama kegiatan berlangsung, terlihat bahwa peserta didik sudah termotivasi untuk mengikuti pelajaran disebabkan adanya keberanian untuk mengemukakan pendapat dan adanya tugas yang diberikan pada setiap pertemuan. Peserta didik diharapkan memperlihatkan sejauh mana penguasaan materi yang telah diajarkan. Namun pada akhir siklus ini peserta didik sudah memperlihatkan aktivitas yang cukup baik dalam belajar. Seperti peserta didik sebagian besar memperhatikan pelajaran, berani bertanya kepada guru, berani mengemukakan pendapat. Hal ini berarti kualitas belajar sudah ada peningkatan.

Berdasarkan hasil perhitungan nilai hasil belajar peserta didik, terlihat bahwa pada tes awal, persentase ketuntasan secara klasikal peserta didik ialah $28 \%$ dengan kategori sangat kurang. Setelah dilakukan tindakan pada siklus I adalah $66 \%$ dan meningkat menjadi $100 \%$ siklus II yang artinya berada pada kategori sangat tinggi.

Hal ini menunjukkan bahwa desain media Power Point yang digunakan oleh guru meningkatan hasil belajar peserta didik kelas IX-4 MTs Negeri 7 Blitar disebabkan karena pada siklus II, peran aktif peserta didik lebih ditingkatkan dengan cara mendorong peserta didik untuk aktif bertanya serta memberi kesempatan yang sama bagi setiap peserta didik untuk berpartisipasi dalam kegiatan pembelajaran. Selain itu, pengajar terlebih dahulu menginformasikan kepada peserta didik tentang hasil ujian mereka kemudian memperjelas tujuan dan manfaat pengetahuan yang diperoleh peserta didik selama pembelajaran serta menghubungkan topik yang akan diajarkan dengan topik yang telah dibahas sebelumnya.

Pembelajaran interaktif dengan bantuan presentasi Microsoft PowerPoint dapat meningkatkan pemahaman materi peserta didik. Karena dengan tampilan-tampilan atau ikonikon yang dimanfaatkan di dalam Microsoft PowerPoint dapat memotivasi peserta didik untuk memperhatikan materi yang sedang disampaikan sehingga apa yang di terangkan oleh guru dapat dimengerti oleh peserta didik. Hal tersebut sejalan dengan pendapat Hamalik (2008:11) menyebutkan bahwa "Jenis teknologi yang digunakan dalam pengajaran terdiri dari media 
audio visual (film, filmstrip, televisi, kaset dan video) dan komputer yang memiliki peran utama untuk memproses informasi secara cermat, cepat dengan hasil yang akurat. Sebagai sebuah media pembelajaran yang dapat meningkatkan minat dan perhatian peserta didik terhadap mata pelajaran tertentu".

Berdasarkan hasil pengamatan aktivitas belajar peserta didik selama proses pembelajaran terlihat adanya perubahan aktivitas belajar peserta didik dari siklus I ke siklus II. Hal ini ditandai dengan meningkatnya peran aktif peserta didik selama proses pembelajaran dan menurunnya persentase peserta didik yang melakukan kegiatan lain selama proses belajar mengajar berlangsung. Dari hasil pengamatan observer di siklus I, diperoleh data bahwa ada beberapa peserta didik yang tidak memperhatikan penjelasan guru yang menggunakan Power Point. Hal ini disebabkan karena peserta didik tersebut hanya bercerita dan melakukan kegiatan yang lain seperti mengerjakan pekerjaan rumah untuk mata pelajaran lain. Namun setelah dilakukan refleksi, pada siklus II diperoleh data pengamatan bahwa anak tersebut telah memperhatikan penjelasan guru. Refleksi yang dilakukan adalah memberikan pengertian, penjelasan dan arahan untuk mengerjakan tugas, memberikan pernyataan ringan tentang materi pelajaran, serta menggali pengalaman awal peserta didik sebelum memasuki materi pelajaran. Perbaikan aktivitas tersebut terlihat bahwa pada semua pertemuan di siklus II di mana $100 \%$ peserta didik telah beraktivitas sesuai indikator pengamatan guru.

Terjadinya peningkatan persentase aktivitas peserta didik dari siklus I ke siklus II menunjukkan bahwa sebagian besar peserta didik memiliki perhatian yang besar dalam belajar IPS khususnya dalam pembelajaran IPS yang menggunakan media pembelajaran Power Point. Peningkatan jumlah peserta didik yang bertanya serta menjawab pertanyaan menunjukkan keinginan peserta didik untuk lebih memahami materi pelajaran dan memecahkan permasalahan yang mereka hadapi serta menunjukkan keberanian mereka untuk bertanya yang patut untuk dihargai. Penggunaan media pembelajaran PowerPoint, dapat meningkatkan motivasi belajar peserta didik yang juga berdampak pada peningkatan aktivitas belajar peserta didik. Karena ketika motivasi belajar tinggi maka aktivitas belajar peserta didikpun akan tinggi yang tentunya diharapkan dapat berdampak pada peningkatan hasil belajar peserta didik.

\section{PENUTUP}

Berdasarkan hasil penelitian maka dapat disimpulkan bahwa desain Pembelajaran berbasis Media Power Point layak digunakan dalam pembelajaran dan dapat meningkatkan kualitas hasil belajar IPS peserta didik MTs Negeri 7 Blitar pada materi letak dan luas benua dengan kategori sangat baik. Karena ada peningkatan motivasi dan hasil belajar peserta didik dalam pelajaran IPS. Hal ini dapat dilihat dari peningkatan persentase nilai peserta didik sebelum dan sesudah diterapkan media Power Point.

\section{DAFTAR PUSTAKA}

Abdullah Sani, Ridwan. 2013. Inovasi Pembelajaran. Jakarta. PT Bumi Aksara.

Abdullah Sani, Ridwan. 2013. Inovasi Pembelajaran. Jakarta. PT Bumi Aksara.

Hakim, Lukmanul. 2011. Perencanaan pembelajaran. Bandung : CV wahana Prima.

Hamalik, Oemar. 2003. Kurikulum dan Pembelajaran. Jakarta: Bumi Aksara.

Isjoni dan Arif Ismail. 2008. Model-model Pembelajaran Mutakhir. Yogyakarta : Pustaka belajar.

Susanto, Ahmad. 2014. Pengembangan Pembelajaran IPS di SD. Jakarta : Pranadamedia Group.

Widada, H. 2010. Cara Mudah Desain Presentasi Dengan Power Point 2007.Yokyakarta: Cakrawala. 